\title{
Antioxidant and antiproliferative activities of Abrus precatorius leaf extracts - an in vitro study
}

\author{
Mir Z Gul ${ }^{1}$, Farhan Ahmad ${ }^{2}$, Anand K Kondapi ${ }^{2}$, Insaf A Qureshi ${ }^{2}$ and Irfan A Ghazi ${ }^{1 *}$
}

\begin{abstract}
Background: The use of traditional medicine at the primary health care level is widespread and plant-based treatments are being recommended for curing various diseases by traditional medical practitioners all over the world. The phytochemicals present in the fruits, vegetables and medicinal plants are getting attention day-by-day for their active role in the prevention of several human diseases. Abrus precatorius is a widely distributed tropical medicinal plant with several therapeutic properties. Therefore in the present study, A. precatorius leaf extracts were examined for their antioxidant and cytotoxic properties in vitro in order to discover resources for new lead structures or to improve the traditional medicine.
\end{abstract}

Methods: In this study, antioxidant and antiproliferative properties of the different leaf extracts (hexane, ethyl acetate, ethanol and water) from A. precatorius were investigated along with the quantification of the polyphenol and flavonoid contents. The ability of deactivating free radicals was extensively investigated with in vitro biochemical methods like DPPH; ' $\mathrm{OH}, \mathrm{NO}, \mathrm{SO}_{2}$ - scavenging assays and inhibition capability of Fe(II)-induced lipid peroxidation. Furthermore, antiproliferative activities using different human cancer cell lines and primary cell line was carried out by MTT method.

Results: Total phenolic content and total flavonoid content of the extracts were found in the range of $1.65 \pm 0.22$ to $25.48 \pm 0.62 \mathrm{GAE} \mathrm{mg} / \mathrm{g} \mathrm{dw}$ and $6.20 \pm 0.41$ to $17.16 \pm 1.04 \mathrm{QE} \mathrm{mg} / \mathrm{g} \mathrm{dw}$ respectively. The experimental results further revealed that $A$. precatorius extracts showed strong antiradical properties, capable to chelate $\mathrm{Fe}^{2+}$ and possess good inhibition ability of lipid peroxidation. In addition, as a first step towards the identification of phytoconstituents endowed with potent chemopreventive activities, we evaluated the inhibitory effects of $A$. precatorius extracts on the proliferation of four different human tumour cell lines such as human colon adenocarcinoma cells (Colo-205), human retinoblastoma cancer cells (Y79), human hepatocellular carcinoma cells (HepG2) and Leukemia cells (SupT1). Ethanol extract (APA) and ethyl acetate extract (APE) of A. precatorius had apparent capabilities of inhibiting the survival of tested human cancer cell lines. Moreover, it was observed that the A. precatorius extracts did not inhibit the growth of mice peritoneal macrophages, thus confirming that plants extracts are selective against the cancer cell lines.

Conclusion: This work provides a scientific support for the high antioxidant and antiproliferative activity of this plant and thus it may find potential applications in the treatment of the diseases caused by ROS. Further studies are needed to confirm in vivo anti-tumorgenicity and subsequent chemical characterization of the active molecule(s).

\footnotetext{
* Correspondence: irfan@uohyd.ernet.in

${ }^{1}$ Department of Plant Sciences, School of Life Sciences, University of Hyderabad, Prof. C. R. Rao Road, Gachibowli, Hyderabad 500 046, India Full list of author information is available at the end of the article
} 


\section{Background}

The human body possesses numerous antioxidant defences and repair mechanisms against oxidative stress. However, these mechanisms are insufficient to prevent the damage entirely as production of reactive oxygen species (ROS) is certain to play multiple important roles in tissue damage and loss of function in a number of tissues and organs [1]. Free radicals and ROS have been implicated as endogenous initiators in the etiology of cancer and several other degenerative or pathologic processes of various serious diseases, as well as in aging processes [2]. Oxidative damage to DNA is considered a critical step in cancer development [3]. Over the past decade or so, numerous experimental and epidemiological studies have shown that a wide variety of phytochemicals such as phenolics, flavonoids, isoflavone, flavones, anthocyanins, catechin, isocatechin and carotenoids are able to prevent or slow down oxidative stressinduced damage leading to carcinogenesis by upsetting the molecular events in the initiation, promotion or progression conditions. Recent studies demonstrated that the high dietary intake of fruits and vegetables could be associated with lower cancer prevalence in humans [4-7]. Natural products mainly from plant kingdom offer a wide range of biologically active compounds that act as natural antioxidants with recognized potential in drug discovery and development [8]. Great interest is currently being paid to natural products for their interesting anticancer activities. High percentages $(\sim 60 \%)$ of all the drugs applied in the treatment and/or prevention of cancer are from natural products and their derivatives, of which higher plants contribute around 25\%. Approximately $60 \%$ of drugs approved for cancer treatment are of natural origin $[9,10]$. This has elicited the pursuit of effective antioxidant and anticancer agents from various sources particularly medicinal and edible plants [11]. Investigations on natural products have regained prominence in the recent past with increasing understanding of their biological significance such as antioxidant, radical scavenging, antiproliferative activities and increasing recognition of the origin and function of their structural diversity [12-15].

Abrus precatorius L. (Fabaceae) is a vine originally native to India that is now commonly found throughout the tropical and subtropical parts of the world [16]. It grows best in fairly dry regions at low elevations. Leaves, roots and seeds are used as a medicament in traditional system of Indian medicine for antihelminthic, antidiarrhoeal, antiemetic and inhibits intestinal motility. Researchers have reported that seeds are used for the treatment of diabetes and chronic nephritis [17]. The leaves of $A$. precatorius are sweeter $[18,19]$ and as equivalent in sweetness potency to sucrose [20]. In West Tropical Africa, A. precatorius leaves have been employed to sweeten foods and certain medicines used for stomach complaints, to treat fevers, cough and cold (used as decoction). The leaves are casually chewed and the vine sometimes sold as a masticatory in Curacao $[21,22]$. The plant is also traditionally used to treat tetanus, and to prevent rabies. Though considerable work has been done on the seeds for different activities, however, scientific information on antioxidant and antiproliferative properties of leaves of this plant is still not available or rather scarce. Thus, we evaluated the abilities of leaf extracts of $A$. precatorius to function as an antioxidant agent using in vitro assays. Additionally, the ability of the leaf extracts to inhibit proliferation of various cancer cell lines was investigated. Since elimination of cancer in early stages is an integral part of chemoprevention, measuring antiproliferative properties against cancer cells provide useful insight on the chemoprotective potential of natural extracts. Thus, the objective of this study was to examine the efficacy of $A$. precatorius as an antioxidant as well as its inhibitory effect on human cancer cell proliferation.

\section{Methods}

\section{Chemicals}

The analytical grade chemicals were purchased from $\mathrm{Hi}$ Media and Merck, India. Standard drugs were purchased from Sigma-Aldrich chemicals co. (Germany); RPMI1640, DMEM and foetal bovine serum (FBS) from Gibco (USA).

\section{Plant material}

Abrus precatorius leaves were kindly provided by Central Research Institute of Unani Medicine, Hyderabad. A voucher specimen (UoH/VS/AP-2) has been preserved in our laboratory for future reference.

\section{Preparation of extracts}

The air-dried leaves of the plant were powdered with a mechanical grinder to obtain a coarse powder, which was then subjected to successive extraction in a soxhlet apparatus using hexane, ethyl acetate, ethanol and water. Each time before extracting with the next solvent, the material was dried in hot air oven at $40^{\circ} \mathrm{C}$. Extracts were then filtered through a Whatman No.1 paper filter and concentrated to the dry mass with the aid of rotary evaporator. The extraction process was repeated three times at different time periods. It was observed that there was no significant difference in the percentage yield and content of phyto-constituents that are believed to play an important role in biological activities. The yield of each extract was measured and residues were stored in dark glass tubes for further analysis. The different extracts were designated as APH (for hexane extract), APE (for ethyl acetate extract), APA (for ethanol 
extract) and APW (for water extract). The dried extracts were dissolved in dimethyl sulfoxide (DMSO) as $20 \mathrm{mg} /$ $\mathrm{mL}$ and diluted with phosphate-buffered saline (PBS, $\mathrm{pH}$ 7.4) to give final concentrations.

\section{Determination of phytoconstituents Determination of total phenols}

Total phenolics were determined using Folin-Ciocalteu reagent as described by Yang et al. [23] with minor modifications. Total phenolic assay was conducted by mixing $2.7 \mathrm{~mL}$ of deionised water, $0.01 \mathrm{~mL}$ of extracts, $0.3 \mathrm{~mL}$ $20 \% \mathrm{Na}_{2} \mathrm{CO}_{3}$ and $0.10 \mathrm{~mL}$ Folin-Ciocalteu reagent. Absorbance of mixture was measured at $725 \mathrm{~nm}$. A standard curve was prepared with gallic acid $\left(r^{2}=0.9454\right)$ and final results were given as $\mathrm{mg}$ gallic acid equivalents (GAE) g dw.

\section{Determination of total flavonoids}

The total flavonoids was measured by addition of aluminium chloride reagent to the solution containing the extract using the method of Barrera et al. [24]. Briefly, $10 \mu \mathrm{L}$ of plant extracts of known concentrations $(20 \mathrm{mg} /$ $\mathrm{mL}$ ) were diluted with $0.5 \mathrm{~mL}$ of double distilled water. To this mixture, $30 \mu \mathrm{L}$ of $5 \%$ sodium nitrite $\left(\mathrm{NaNO}_{2}\right)$ and $60 \mu \mathrm{L}$ of $10 \%$ aluminium chloride were added and incubated at room temperature for $10 \mathrm{~min}$. After incubation, $350 \mu \mathrm{L}$ of $1 \mathrm{M} \mathrm{NaOH}$ was added and total volume was made up to $1 \mathrm{~mL}$ with distilled water. Finally, absorbance was measured against the prepared blank at $510 \mathrm{~nm}$ and results were given as quercetin equivalents (mg QE)/g of dw. Standard curve was prepared with known concentrations of quercetin $\left(r^{2}=0.955\right)$.

\section{Antioxidant ability assays Phosphomolybdenum assay}

The total antioxidant activity of extracts was evaluated by green phosphomolybdenum complex according to the method of Prieto et al. [25]. An aliquot of $10 \mu \mathrm{L}$ of sample solution was mixed with $1 \mathrm{~mL}$ of reagent solution $(0.6 \mathrm{M}$ sulphuric acid, $28 \mathrm{mM}$ sodium phosphate and $4 \mathrm{mM}$ ammonium molybdate) in micro centrifuge tube. Tubes were incubated in a dry thermal bath at $95^{\circ} \mathrm{C}$ for $90 \mathrm{~min}$. After cooling, the absorbance of the mixture was measured at $695 \mathrm{~nm}$ against a blank. Ascorbic acid have been used $\left(r^{2}=0.964\right)$ for reference and the reducing capacities of the analyzed extracts were expressed as mg of ascorbic acid equivalents (mg AAE)/ $\mathrm{g}$ of $\mathrm{dw}$.

\section{Ferric-reducing/antioxidant power (FRAP) assay}

The $\mathrm{Fe}^{3+}$ reducing power of the extracts was determined by the method of Oyaizu [26] with slight modifications. Briefly, extracts and standard (ascorbic acid) in $1 \mathrm{~mL}$ of appropriate solvents were mixed with $2.5 \mathrm{~mL}$ of phosphate buffer $(0.2 \mathrm{M}$, pH 6.6$)$ and $2.5 \mathrm{~mL}$ of potassium ferricyanide (1\%), and then mixture was incubated at $50^{\circ} \mathrm{C}$ for $30 \mathrm{~min}$. Afterwards, $2.5 \mathrm{~mL}$ of trichloroacetic acid $(10 \%)$ was added to the mixture, which was then centrifuged at $5000 \mathrm{rpm}$ for $10 \mathrm{~min}$. Finally, $2.5 \mathrm{~mL}$ of the upper layer solution was mixed with $2.5 \mathrm{~mL}$ of distilled water and $0.1 \mathrm{~mL}$ of $\mathrm{FeCl}_{3}(0.1 \%)$. The absorbance was measured at $700 \mathrm{~nm}$ and the reducing power of the extracts was presented as mg AAE/g of dw.

\section{$D P P H^{\circ}$ radical scavenging activity}

The DPPH free radical scavenging activity of leaf extracts of $A$. precatorius was measured in term of hydrogen donating or radical scavenging ability using the stable radical DPPH [27]. Briefly, $0.004 \% \mathrm{w} / \mathrm{v}$ of DPPH radical solution was prepared in methanol and then $900 \mu \mathrm{L}$ of this solution was mixed with $100 \mu \mathrm{L}$ of extract solution containing $40-400 \mu \mathrm{g} / \mathrm{mL}$ of dried extract. The absorbance was measured at $517 \mathrm{~nm}$ after 30 min of incubation. Methanol (95\%), DPPH solution and ascorbic acid were used as blank, control and reference respectively.

\section{Hydroxyl radical scavenging activity}

The ability of the extracts to inhibit site-specific hydroxyl radical-mediated peroxidation was carried out according to the method given by Hinneburg et al. [28] with some modifications. Briefly, the mixture containing $\mathrm{FeCl}_{3}(10 \mathrm{mM})$, ascorbic acid $(1 \mathrm{mM}), \mathrm{H}_{2} \mathrm{O}_{2}(10 \mathrm{mM})$, deoxyribose $(28 \mathrm{mM})$ and different concentrations of test samples $(40-400 \mu \mathrm{g} / \mathrm{mL})$ in $500 \mu \mathrm{L}$ phosphate buffered saline (PBS, $20 \mathrm{mM}, \mathrm{pH}$ 7.4) was incubated for $30 \mathrm{~min}$ at $37^{\circ} \mathrm{C}$. After adding $1 \mathrm{~mL}$ of trichloroacetic acid $(10 \%, \mathrm{w} / \mathrm{v})$ and $1 \mathrm{~mL}$ thiobarbituric acid $(2.8 \% \mathrm{w} / \mathrm{v}$; in $25 \mathrm{mM} \mathrm{NaOH}$ ), the reaction mixture was boiled for $15 \mathrm{~min}$. The extent of oxidation was estimated at $532 \mathrm{~nm}$ and the scavenging activity of test sample was expressed as the percentage inhibition of the deoxyribose degradation to malondialdehyde. Ascorbic acid was used as the positive control.

\section{Hydrogen peroxide scavenging assay}

The ability of plant extracts to scavenge hydrogen peroxide was determined according to Long et al. [29]. A $40 \mathrm{mM}$ of $\mathrm{H}_{2} \mathrm{O}_{2}$ solution was mixed with different concentrations of plant extracts $(20-200 \mu \mathrm{g} / \mathrm{mL})$ and incubated for $3.5 \mathrm{~h}$ at room temperature. After incubation, $90 \mu \mathrm{L}$ of the $\mathrm{H}_{2} \mathrm{O}_{2}$-sample solution was mixed with 10 $\mu \mathrm{L}$ of HPLC-grade methanol and $0.9 \mathrm{~mL}$ of FOX reagent was added (prepared by mixing 9 volumes of $4.4 \mathrm{mM}$ BHT in HPLC-grade methanol with 1 volume of $1 \mathrm{mM}$ xylenol orange and $2.56 \mathrm{mM}$ ammonium ferrous sulfate in $0.25 \mathrm{M} \mathrm{H}_{2} \mathrm{SO}_{4}$ ). The reaction mixture was vortexed and then incubated at room temperature for $30 \mathrm{~min}$. 
The absorbance of ferric-xylenol orange complex was measured at $560 \mathrm{~nm}$. Ascorbic acid was used as the reference compound.

\section{Nitric oxide scavenging activity}

The free radical scavenging potential of $A$. precatorius was further substantiated by scavenging of nitric oxide radical assayed by sodium nitroprusside method [30]. The reaction solution $(50 \mu \mathrm{L})$ containing $10 \mathrm{mM}$ sodium nitroprusside in PBS ( $\mathrm{pH}$ 7.0) was mixed with different concentration $(40-400 \mu \mathrm{g} / \mathrm{mL})$ of sample extracts, followed by incubation at $37^{\circ} \mathrm{C}$ for 20 min under light. After incubation, the samples were mixed with $300 \mu \mathrm{L}$ of Griess reagent ( $1 \%$ sulfanilamide, $2 \% \mathrm{H}_{3} \mathrm{PO}_{4}$ ). The samples were again incubated for $30 \mathrm{~min}$ at room temperature under light conditions followed by the addition of 0.1\% N-(1-naphthyl) ethylenediamine dihydrochloride. The absorbance was recorded at $546 \mathrm{~nm}$ and the results were expressed as per cent of scavenged nitric oxide with respect to the negative control without addition of any antioxidant. Ascorbic acid was used as a positive control.

\section{Superoxide radicals scavenging activity}

The scavenging activity of the plant extracts towards superoxide anion radicals was measured by the nitro-blue tetrazolium (NBT) reduction method [31] with minor modifications. Superoxide anions were generated in a non-enzymatic phenazine methosulfate nicotinamide adenine dinucleotide (PMS-NADH) system through the reaction of PMS, NADH and oxygen. It was assayed by the reduction of nitroblue tetrazolium. In the experiment, the superoxide anion was generated in $2 \mathrm{~mL}$ of phosphate buffer $(100 \mathrm{mM}, \mathrm{pH}$ 7.4) containing $500 \mu \mathrm{L}$ of $156 \mu \mathrm{M}$ nitroblue tetrazolium (NBT solution), $500 \mu \mathrm{L}$ of $468 \mu \mathrm{M}$ nicotinamide adenine dinucleotide (NADH) solution and $300 \mu \mathrm{L}$ of different concentrations $(40-400 \mu \mathrm{g} / \mathrm{mL})$ of extracts. DMSO and L-ascorbic acid were used as solvent and positive control respectively. The reaction was initiated by adding $100 \mu \mathrm{L}$ of $60 \mu \mathrm{M}$ phenazine methosulfate (PMS) to the mixture. After $5 \mathrm{~min}$ of incubation at room temperature, the absorbance was measured at $560 \mathrm{~nm}$ against blank. Decreased absorbance of the reaction mixture indicated increased superoxide anion scavenging activity.

\section{Inhibition of lipid peroxidation assay}

$\mathrm{Fe}^{2+}$ induced lipid peroxidation is one of the established system for assessing antioxidant action of different plant extracts. A modified thiobarbituric acid-reactive species (TBARS) assay [32] was used to measure the lipid peroxide formed using rat liver homogenate as lipid rich media. Malondialdehyde (MDA), a secondary end product of the oxidation of polyunsaturated fatty acids, reacts with two molecules of TBA yielding a pinkish red chromogen. Healthy albino rats of the wister strain (250 grams) were sacrificed (procedure described was reviewed and approved by the University of Hyderabad, School of Life Sciences' animal ethics committee) and liver was perfused with $0.15 \mathrm{M} \mathrm{KCl}$, homogenate was centrifuged at $800 \mathrm{~g}$ for $15 \mathrm{~min}$ at $4^{\circ} \mathrm{C}$ and the supernatant was used for thiobarbituric acid assay. The extracts of $A$. precatorius at different concentrations $(40-400 \mu \mathrm{g} / \mathrm{mL})$ were mixed with the liver microsome preparation and incubated at room temperature for $10 \mathrm{~min}$. Then, $50 \mu \mathrm{L}$ Fenton's reagent $\left(10 \mathrm{mM} \mathrm{FeCl}_{3} ; 10\right.$ $\mu \mathrm{L}$ of $2.5 \mathrm{mM} \mathrm{H}_{2} \mathrm{O}_{2} ; 0.1 \mathrm{M} \mathrm{L}$-ascorbic acid) in phosphate buffer (0.2 M, pH 7.4) were added, and the volume was made to $1 \mathrm{~mL}$. The tubes were then incubated for $30-45 \mathrm{~min}$ at $37^{\circ} \mathrm{C}$ to induce lipid peroxidation. Thereafter, $2 \mathrm{~mL}$ of ice-cold $\mathrm{HCl}(0.25 \mathrm{~N})$ containing $15 \%$ trichloroacetic acid, $0.5 \%$ thiobarbituric acid and $0.5 \%$ butylated hydroxytoluene (BHT) were added in each sample followed by heating at $100^{\circ} \mathrm{C}$ for $15 \mathrm{~min}$. The reaction mixture was put in an ice bath for $10 \mathrm{~min}$. The mixture was centrifuged at $1000 \mathrm{rpm}$ for $10 \mathrm{~min}$ and the extent of lipid peroxidation was subsequently monitored by formation of thiobarbituric acid reactive substances (TBARS) as pink chromogen in presence or absence of extracts and standard (L-ascorbic acid). The absorbance of the supernatant was measured spectrophotometrically at $532 \mathrm{~nm}$ and decline in formation of pink chromogen in pre-treated reactions was considered as inhibition of lipid peroxidation.

\section{Anti-proliferative activity}

A panel of four human cell lines namely, (a): human colon adenocarcinoma cells - Colo-205, (b): human retinoblastoma cancer cells - Y79, (c): human hepatocellular carcinoma cells - HepG2 and (d): Leukaemia cells SupT1 were used to study antiproliferative activity. The cell lines were obtained from National Centre for Cell Sciences (NCCS), Pune, India. The cell lines HepG2 \& Colo-205 were cultured in Dulbecco's modified Eagle's medium (DMEM) and Y79 \& SupT1 in RPMI 1640 containing $10 \%(\mathrm{v} / \mathrm{v})$ FBS, 100 units/mL penicillin and $100 \mu \mathrm{g} / \mathrm{mL}$ streptomycin. Cells were maintained in a humidified incubator with $5 \% \mathrm{CO}_{2}$ for $24 \mathrm{~h}$ at $37^{\circ} \mathrm{C}$ and seeded onto $75 \mathrm{~cm}^{2}$ culture flasks. In vitro response to extracts and standard drug was evaluated by means of a growth inhibition using the MTT assay [33]. The cells were seeded at a density of $\sim 5 \times 10^{3}$ per well using a brief trypsinization. Furthermore, Doxorubicin and sample extracts $(25-200 \mu \mathrm{g} / \mathrm{mL})$ dissolved in dimethylsulfoxide (DMSO; not exceeding the concentration of 2\%), and further diluted in cell culture medium were added into a 96-well plate. After $48 \mathrm{~h}$ of incubation, $20 \mu \mathrm{L}$ of MTT reagent $(5 \mathrm{mg} / \mathrm{mL})$ were added and mixtures were reincubated for $4 \mathrm{~h}$. Finally the 
absorbance of formazan was measured at $550 \mathrm{~nm}$. Doxorubicin was also assayed as a positive control at the concentration of $0.5-10 \mu \mathrm{g} / \mathrm{mL}$. The resulting growth data represents the net outcome of cell proliferation and cell death. The cell viability (\%) was obtained by comparing the absorbance between the samples and a negative control.

\section{Assessment of extract toxicity in normal cells}

To assess the toxicity of the plant extracts on primary cells (peritoneal murine macrophages), the MTT toxicity assay was used. Thioglycollate-elicited mouse peritoneal macrophages were harvested from female BALB/C mice [34]. Experimental protocol was again undertaken in accordance with the ethical guidelines and the permission of the University of Hyderabad, School of Life Sciences' animal ethics committee was obtained. Toxicity toward mouse peritoneal macrophages was assessed with cells plated in 96-well plates at a density of $2 \times 10^{6}$ cells per well (in $200 \mu \mathrm{L}$ volume). After adherence, the medium was removed and replaced by one of the media containing the plant extracts. The plates were incubated for $72 \mathrm{hrs}$ at $37^{\circ} \mathrm{C}$ in a humidified $5 \% \mathrm{CO}_{2}$ incubator. Control cells were incubated with culture medium alone. Cell viability was determined by a colorimetric assay with the tetrazolium salt MTT [33]. Absorbance of the formed formazan product was measured at a test wavelength of $540 \mathrm{~nm}$. Results were expressed as percentage cellular viability of the extracts.

\section{Calculations and statistical analysis}

The percentage inhibitions of radicals, lipid peroxidation and cytotoxic activities of the extracts were calculated using the formula:

Percentage inhibition $=\left(A_{\text {control }}-A_{\text {sample }}\right) / A_{\text {control }} \times 100$

All results are expressed as mean \pm standard deviation (SD) values average from 3 to 4 independent experiments performed in duplicate. $\mathrm{IC}_{50}$ value (the concentration of the extracts required to scavenge $50 \%$ of radicals) was calculated for different extracts of $A$. precatorius.

Statistical differences between correlated samples were evaluated using Student's $t$-test and composite treatments were compared using one-way analysis of variances (ANOVA) and considered significantly different where probability values were found to be equal to or less than 0.05. Statistical tests as well as mean and SD calculations and graphical representation of the results were performed using GraphPad Prism v5 and Sigmaplot v11.0 software's.

\section{Results and discussion}

\section{Determination of phyto-constituents}

The results of total phenolic content in leaf extracts of A. precatorius evaluated using Folin-Ciocalteu method are presented in Table 1 . Total polyphenolic content in different extracts varied with the solvent used in this study. The results indicated that water extract (APW) possessed an abundance of phenolics amounting to $25.48 \pm 0.62 \mathrm{mg} \mathrm{GAE} / \mathrm{g} \mathrm{dw}$, while GAE value of ethyl acetate (APE) extract was $23.57 \pm 0.31 \mathrm{mg} / \mathrm{g} \mathrm{dw}$. Ethanol extract (APA) and hexane extract (APH) showed less amount of GAE at $7.44 \pm 0.10 \mathrm{mg} / \mathrm{g} \mathrm{dw}$ and $1.65 \pm$ $0.22 \mathrm{mg} / \mathrm{g} \mathrm{dw}$ respectively. It suggested that major phenolics of $A$. precatorius were mainly located in water extract. The extracts of $A$. precatorius also contained significant amount of flavonoids (Table 1). The flavonoid contents of extracts in terms of quercetin equivalents were between $6.20 \pm 0.41$ and $17.16 \pm 1.04 \mathrm{mg} / \mathrm{g} \mathrm{dw}$. The flavonoid contents in APE $(17.16 \pm 1.04 \mathrm{mg} / \mathrm{g} \mathrm{dw})$ was higher compared to other three extracts. The plant derived antioxidants especially polyphenols and flavonoids have recently attracted medicinal attention as bioactive agents with anticancer, antidiabetic, antimicrobial, hepatoprotective, neuroprotective and cardioprotective properties [35-37]. They have been ascribed to have resilient antioxidant activity and help in protecting cells against oxidative damage caused by free radicals due to their redox properties, which enable them to act as reducing agents, hydrogen donors and singlet oxygen quenchers [38-41].

\section{Antioxidant ability assays Phosphomolybdenum assay}

In phosphomolybdenum assay, which is a quantitative method to evaluate the antioxidant capacity, all the extracts exhibited different degrees of activity as shown in Table 1 . The reducing power of a compound is associated with electron donating capacity and serves as an indicator of antioxidant activity [42,43]. Results indicated that APA has higher antioxidant capacity (24.73 \pm $0.72 \mathrm{mg}$ ascorbic acid equivalent/g dw) than other three extracts which showed antioxidant capacity in the order: APE $(17.92 \pm 0.38 \mathrm{mg}$ AAE $/ g \quad \mathrm{dw})>\mathrm{APW} \quad(16.66 \pm$ $0.68 \mathrm{mg} \mathrm{AAE} / \mathrm{g} \mathrm{dw})>\mathrm{APH}(7.16 \pm 0.43 \mathrm{mg} \mathrm{AAE} / \mathrm{g} \mathrm{dw})$.

\section{Ferric-reducing/antioxidant power (FRAP) assay}

In reducing power assay, the presence of reductants (antioxidants) in samples would result in the reduction of $\mathrm{Fe}^{3+}$ to $\mathrm{Fe}^{2+}$ by donating an electron which serves as a significant reflection of antioxidant activity [44]. The amount of $\mathrm{Fe}^{2+}$ complex can be monitored by measuring the formation of Perl's Prussian blue at $700 \mathrm{~nm}$. Increasing absorbance at $700 \mathrm{~nm}$ indicates an increase in reductive ability [45]. Earlier reports suggest that some phenolic 
Table 1 Quantitative estimation of phytochemicals and antioxidant activities of different extracts of $A$. precatorius

\begin{tabular}{ccccc}
\hline Type of Extract & Total Phenols $^{\mathbf{a}}$ & Total Flavonoid $^{\mathbf{b}}$ & Total antioxidant capacity $^{\mathbf{c}}$ & Ferric reducing antioxidant power $^{\mathbf{c}}$ \\
\hline APH & $1.65 \pm 0.22$ & $6.20 \pm 0.41$ & $7.16 \pm 0.43$ & $2.67 \pm 0.40$ \\
APE & $23.57 \pm 0.31$ & $17.16 \pm 1.04$ & $17.92 \pm 0.38$ & $8.45 \pm 0.65$ \\
APA & $7.44 \pm 0.10$ & $7.23 \pm 0.68$ & $24.73 \pm 0.72$ & $10.28 \pm 0.47$ \\
APW & $25.48 \pm 0.62$ & $10.70 \pm 0.56$ & $16.66 \pm 0.68$ & $13.34 \pm 0.35$ \\
\hline
\end{tabular}

a: Gallic acid; b: Quercetin; c: Ascrobic acid equivalents $\mathrm{mg} / \mathrm{g} \mathrm{dw}$ plant material respectively. Each value is expressed as a mean \pm standard deviation $(\mathrm{n}=3$ ).

compounds such as flavonoids and phenolic acids exhibited antioxidant activity through their reductive capacity in a $\mathrm{Fe}^{3+}-\mathrm{Fe}^{2+}$ system [46]. All the four extracts showed some degree of electron donating capacity and reduced $\mathrm{Fe}^{3+}$ to $\mathrm{Fe}^{2+}$. The reducing ability of the extracts was in range of $13.34 \pm 0.35$ to $2.67 \pm 0.40 \mathrm{AAE} \mathrm{mg} / \mathrm{g} \mathrm{dw}$ (Table 1). The FRAP values for APW was found to be higher than other three extracts. This suggests that APW has a significant ability to react with free radicals to alter them into more stable non-reactive species and to terminate radical chain reaction.

\section{$D P P H^{\circ}$ radical scavenging activity}

DPPH assay provides basic information on antiradical activity of extracts and its results can indicate the presence of phenolic and flavonoid compounds in plant extracts [47]. Very significant antioxidant activities were found in all the four extracts and positive control, which increased with increasing concentration (Figure 1). DPPH activity values for APE, APA and APW were found to be nearer to each other. The APE and APW were able to inhibit the formation of $\mathrm{DPPH}^{*}$ radicals with a percentage inhibition of $96.35 \pm 2.98$ and $92.63 \pm$ $4.63 \%$ respectively at the highest concentration of $400 \mu \mathrm{g} / \mathrm{ml}$ with the $\mathrm{IC}_{50}$ values of $57.66 \pm 1.32$ and 79.97 $\pm 1.84 \mu \mathrm{g} / \mathrm{mL}$ respectively (Table 1 ). Previous reports have demonstrated that ethyl acetate fractions are good

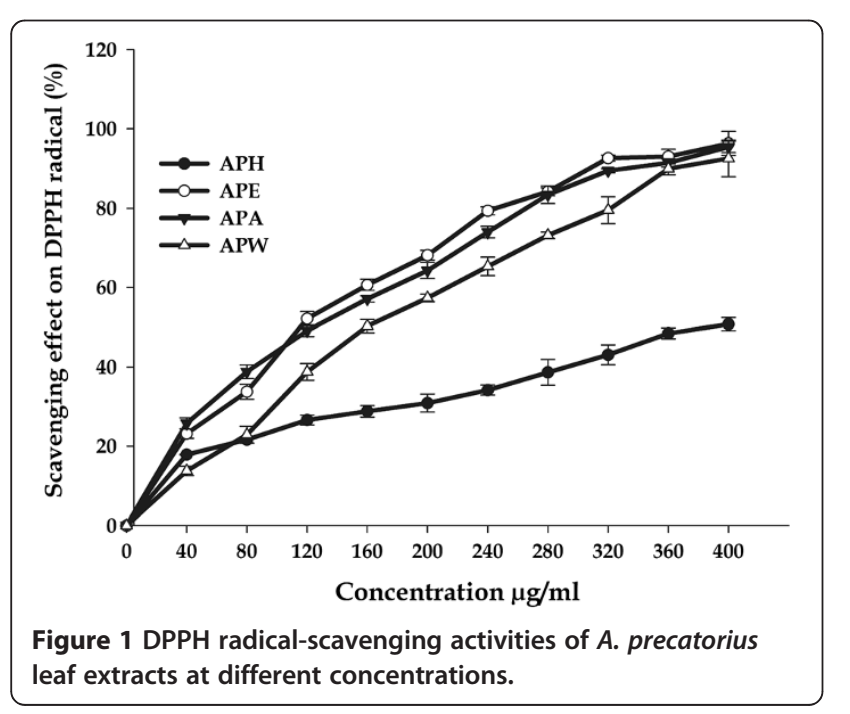

sources of antioxidant compounds $[48,49]$. APA also exhibited potent DPPH scavenging activity (95.14 \pm $3.44 \%)$ in this study and its $\operatorname{IC}_{50}(60.67 \pm 1.03 \mu \mathrm{g} / \mathrm{mL})$ was near to that of APE, in which phenolic levels were approximately 3.5 times higher. Several groups have pronounced a positive correlation between phenolic content and antioxidant activity [50-52] using similar assay systems, but our study could not establish correlation in similar manner. It could be due to the presence of other reducing compounds that probably interfere with the Folin-Ciocalteu assay and/or the presence of other nonphenolic compounds with antioxidant effects. $\mathrm{APH}$ showed less inhibitory action as compared to other extracts with the percentage inhibition of $50.84 \pm 5.68$ at same concentration with the $\mathrm{IC}_{50}$ value $196.70 \pm 1.84 \mu \mathrm{g} /$ $\mathrm{mL}$. The $\mathrm{IC}_{50}$ values of ascorbic acid and quercetin (positive controls) were found to be $3.80 \pm 0.43$ and $9.84 \pm$ $0.6 \mu \mathrm{g} / \mathrm{mL}$ respectively. This behaviour can be explained by different composition of each extracts as there are compounds that react quickly with DPPH and others that have a slower reaction mechanism and required extremely high concentration to have a significant effect [53].

\section{Hydroxyl radical scavenging activity}

The hydroxyl radical is known to be the most reactive oxygen radical and it severely damages neighbouring bio-molecules in the body, such as protein and DNA, resulting into mutagenesis, carcinogenesis and cytotoxicity $[54,55]$. Therefore, removal of hydroxyl radical is possibly one of the most effective defences of a living body against various diseases. A significant decrease in concentration of hydroxyl radical was observed due to A. precatorius extracts (Figure 2; Table 2). All the extracts exhibited significant activity, above $40 \%$ in a concentration - dependent manner with maximal inhibition of $79.52 \pm 2.57 \%$ at $400 \mu \mathrm{g} / \mathrm{mL}$ by APE with $\mathrm{IC}_{50}$ value of $205.51 \pm 3.08 \mu \mathrm{g} / \mathrm{mL}$. APA $\left(78.97 \pm 1.60 \%\right.$; $\mathrm{IC}_{50}=$ $209.33 \pm 4.13 \mu \mathrm{g} / \mathrm{mL})$ and $\mathrm{APW}\left(68.18 \pm 3.14 \% ; \mathrm{IC}_{50}=\right.$ $309.90 \pm 5.21 \mu \mathrm{g} / \mathrm{mL}$ ) extracts were also found to be significant powerful quenchers of ${ }^{\circ} \mathrm{OH}$ radical as compared to ascorbic acid $\left(\mathrm{IC}_{50}=62.40 \pm 3.72\right)$. $\mathrm{APH}$ was found to be weak scavenger of ${ }^{\circ} \mathrm{OH}$ with the $I C_{50}$ value of $464.25 \pm 4.43 \mu \mathrm{g} / \mathrm{mL}$. Our results suggested that hydroxyl radical scavenging ability of extracts of $A$. precatorius are comparable to or even higher than 


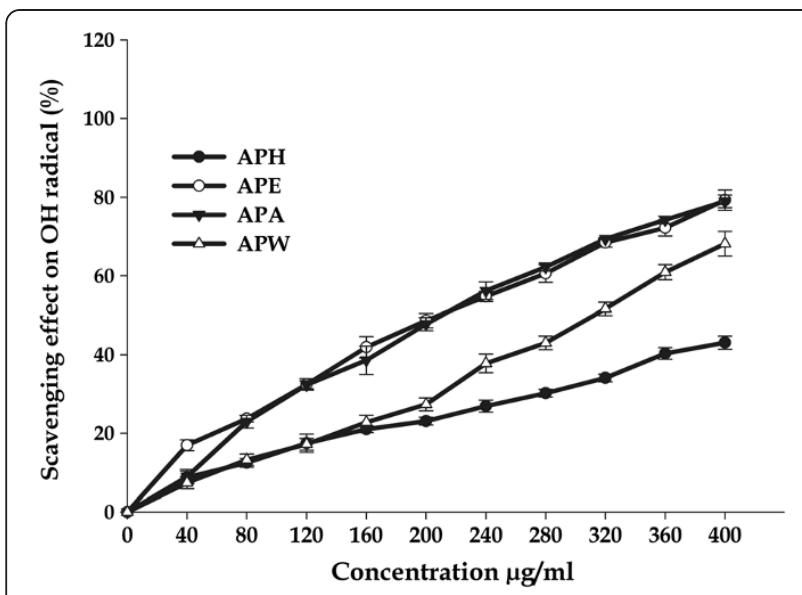

Figure 2 Hydroxyl radical scavenging activities of $A$. precatorius leaf extracts at different concentrations.

earlier published reports [12,56,57] and could help in preventing oxidative damage in the human body.

\section{Hydrogen peroxide scavenging assay}

Hydrogen peroxide $\left(\mathrm{H}_{2} \mathrm{O}_{2}\right)$ is a biologically relevant, non-radical reactive oxygen species and is inevitably generated as a by-product of normal aerobic metabolism. However, when concentration increases under stress conditions, $\mathrm{H}_{2} \mathrm{O}_{2}$ could be detrimental for cells [58] and, furthermore, could be converted into other ROS such as hydroxyl radicals. Thus, $\mathrm{H}_{2} \mathrm{O}_{2}$ scavenging activity becomes a crucial characteristic of total antioxidant activity. In this study, APA extract $\left(\mathrm{IC}_{50}=92.83 \pm\right.$ $3.23 \mu \mathrm{g} / \mathrm{ml}$ ) was found to be efficient scavenger of hydrogen peroxide radical, while $\mathrm{APW}$ extract $\left(\mathrm{IC}_{50}=\right.$ $152.35 \pm 1.06 \mu \mathrm{g} / \mathrm{mL}$ ) was least efficient. The APH and APE extracts also exhibited comparable efficiency with $\mathrm{IC}_{50}=112.59 \pm 3.24$ and $121.02 \pm 3.14 \mu \mathrm{g} / \mathrm{mL}$ respectively (Figure 3; Table 2). The $\mathrm{H}_{2} \mathrm{O}_{2}$ scavenging capacity of all extracts was also better than that of quercetin tested in the same conditions. The results strongly suggest that these extracts contain the necessary compounds for radical elimination. Many reports have already proven that nutritive phenols play a significant role in protecting mammalian and bacterial cells from cytotoxicity induced by $\mathrm{H}_{2} \mathrm{O}_{2}$ [59-61], indicating that the observed activity of plants extracts could be due to the presence of phenols.

\section{Nitric oxide scavenging activity}

Initially NO was regarded to have only beneficial effects, but it has been found that over production of NO is closely associated with different pathological diseases, such as chronic inflammation, autoimmune diseases and cancer [62]. The NO radicals play an important role in inducing inflammatory response and their toxicity multiplies only when they react with $\mathrm{O}_{2}^{-}$radicals to form peroxynitrite which damages the biomolecules such as proteins, lipids and nucleic acids, and therefore injures the host tissue [56]. The measure of NO radical scavenging activity was based on the principle that sodium nitroprusside in an aqueous solution at physiological $\mathrm{pH}$ spontaneously generates nitric oxide, which interacts with oxygen to produce nitrite ions that can be estimated using a Griess reagent. Scavengers of nitric oxide act against oxygen, leading to reduced production of nitrite ions which can be monitored at $546 \mathrm{~nm}$. A. precatorius extracts showed significant decrease in $\mathrm{NO}$ radical due to the scavenging ability of extracts. All the extracts exhibited significant NO scavenging activity in a concentration dependent manner (Figure 4). The results clearly identify APE as better NO scavenger where percentage inhibition reached to $97.58 \pm 3.12 \%$ with an $\mathrm{IC}_{50}$ value of $107.58 \pm 2.12 \mu \mathrm{g} / \mathrm{mL}$ followed by APA whose inhibition of generation of NO reached up to $92.70 \pm 2.13$ $\left(\mathrm{IC}_{50}=145.96 \pm 2.17 \mu \mathrm{g} / \mathrm{mL}\right)$ in a concentration dependent manner and a gradual decline thereafter at the higher concentrations. The APH and APW extracts were also efficient scavengers of $\mathrm{NO}(83.11 \pm 0.89 \%$ and $80.62 \pm 2.11 \%$ ) with slightly higher $\mathrm{IC}_{50}$ Values, $192.45 \pm$ 3.76 and $264.95 \pm 4.24 \mu \mathrm{g} / \mathrm{mL}$ respectively.

\section{Superoxide radicals scavenging activity}

Superoxide anion $\left(\mathrm{O}_{2}^{-}\right)$is one of the most important representatives of free radicals. It acts as a precursor of more reactive oxidative species such as single oxygen and hydroxyl radicals that have the potential of reacting

Table 2 IC $_{50}$ values obtained in the antioxidant activity assays

\begin{tabular}{|c|c|c|c|c|c|c|}
\hline \multirow[t]{2}{*}{ Sample } & \multicolumn{6}{|c|}{$\mathrm{IC}_{50} \mu \mathrm{g} / \mathrm{mL}$} \\
\hline & DPPH & $\mathrm{OH}$ & $\mathrm{H}_{2} \mathrm{O}_{2}$ & NO & $\mathrm{O}_{2}^{-1}$ & Lipid peroxidation \\
\hline $\mathrm{APH}$ & $196.70 \pm 2.06$ & $464.25 \pm 4.43$ & $112.59 \pm 3.24$ & $192.45 \pm 3.76$ & $427.26 \pm 5.72$ & $377.07 \pm 5.23$ \\
\hline APE & $57.66 \pm 1.32$ & $205.51 \pm 3.08$ & $121.02 \pm 3.14$ & $107.58 \pm 2.12$ & $143.44 \pm 3.28$ & $45.46 \pm 3.71$ \\
\hline APA & $60.67 \pm 1.03$ & $209.33 \pm 4.13$ & $92.83 \pm 3.23$ & $145.96 \pm 2.17$ & $157.07 \pm 2.56$ & $285.22 \pm 4.63$ \\
\hline APW & $79.97 \pm 1.84$ & $309.90 \pm 5.21$ & $152.35 \pm 1.06$ & $264.95 \pm 4.24$ & $201.45 \pm 6.23$ & $302.02 \pm 4.11$ \\
\hline Ascorbic acid & $6.86 \pm 0.92$ & $62.40 \pm 3.72$ & - & $19.90 \pm 2.30$ & $32.86 \pm 3.78$ & $48.72 \pm 3.20$ \\
\hline Quercetin & $14.34 \pm 1.64$ & - & $245.30 \pm 4.60$ & $21.09 \pm 2.16$ & - & - \\
\hline
\end{tabular}

Each value is expressed as a mean \pm standard deviation $(n=3)$. 


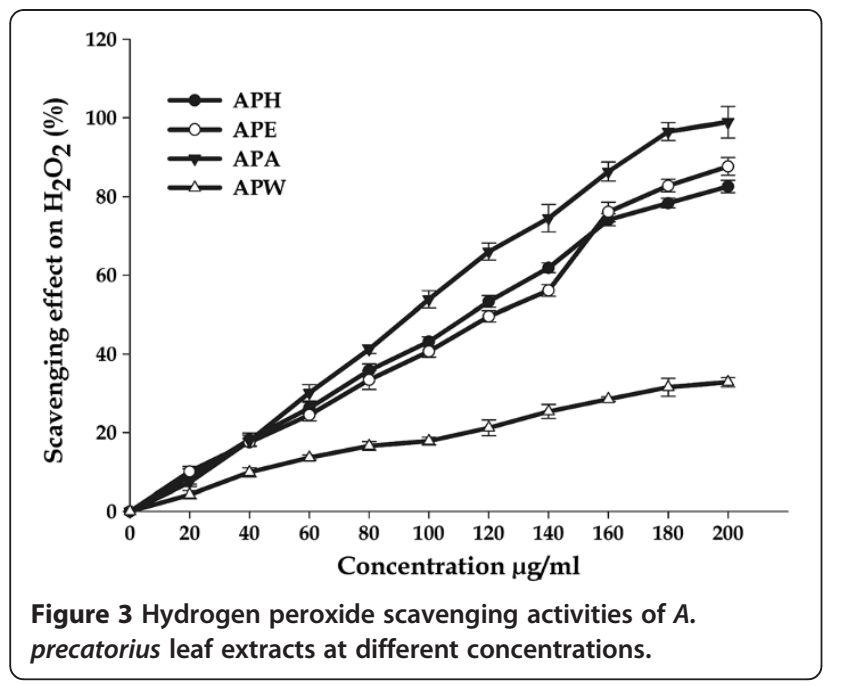

with biological macromolecules and thereby inducing tissue damage, and plays a vital role in peroxidation of lipids [63-65]. In the present study, the inhibitory effect of $A$. precatorius extracts on superoxide radicals was in a concentration dependent manner (Figure 5). High inhibitions were observed at very low extract concentrations. At $400 \mu \mathrm{g} / \mathrm{mL}$ of tested extract, the scavenging effects on superoxide radical were found to be $95.01 \pm 4.29 \%$; $\mathrm{IC}_{50}$ value $=143.44 \pm 3.28 \mu \mathrm{g} / \mathrm{mL}$ for APE and $93.15 \pm 4.36 \%$; $\mathrm{IC}_{50}$ value $=157.07 \pm 2.56 \mu \mathrm{g} / \mathrm{mL}$ for APA. Moreover, APW and APH also possess the significant scavenging effect $73.25 \pm 4.50 \%$; $\mathrm{IC}_{50}$ value $=201.45 \pm 6.23 \mu \mathrm{g} / \mathrm{mL}$ and $46.81 \pm 2.87 \% ; \mathrm{IC}_{50}$ value $=427.26 \pm 5.72 \mu \mathrm{g} / \mathrm{mL}$ respect ively, however with higher $\mathrm{IC}_{50}$ values.

\section{Inhibition of lipid peroxidation assay}

Lipid peroxidation involves the formation and propagation of lipid radicals with numerous deleterious effects,

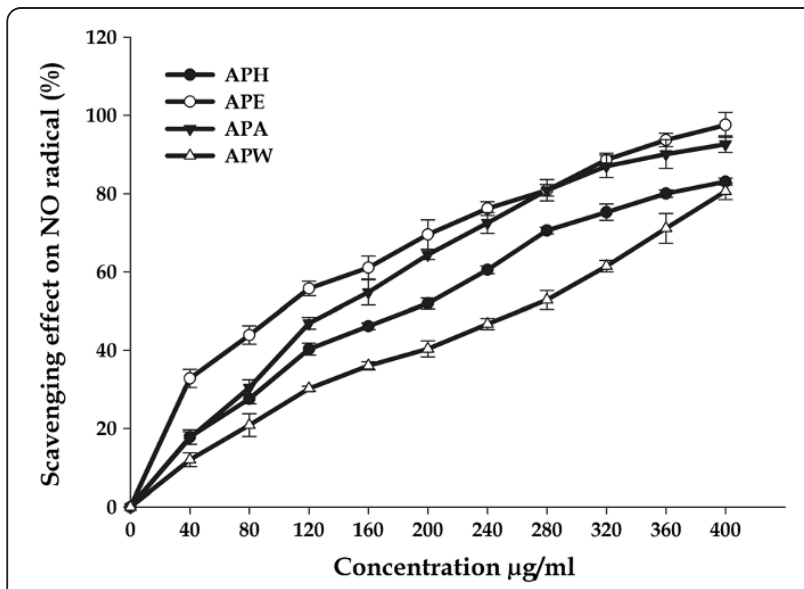

Figure 4 Nitric oxide scavenging activities of $A$. precatorius leaf extracts at different concentrations.

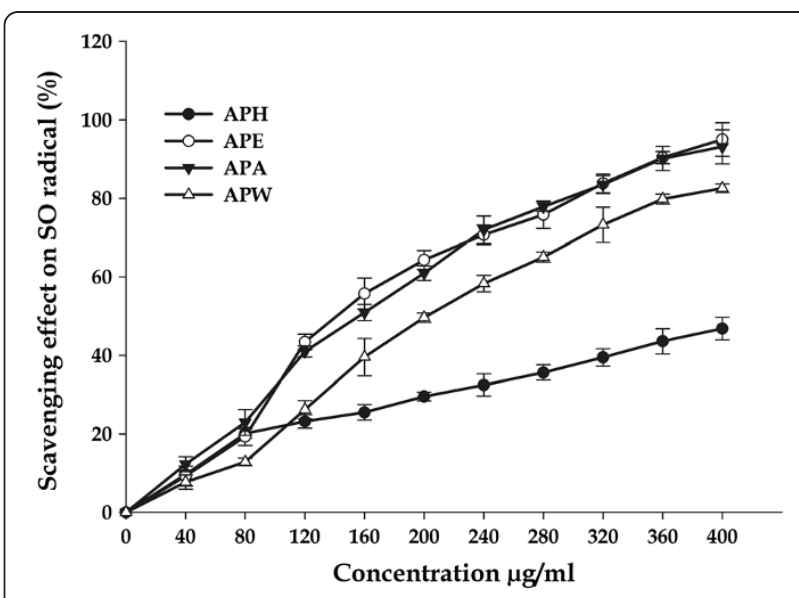

Figure 5 Superoxide scavenging activities of different extracts of $A$. precatorius at different concentrations.

including destruction of membrane lipids, metabolic disorders and inflammation. Production of malondialdehyde (MDA) is a hallmark of this process. This process is initiated by hydroxyl and superoxide radicals leading to the formation of peroxy radicals (LOO) that ultimately propagates chain reaction in lipids. Thus, antioxidants which are capable of scavenging peroxy radicals could prevent lipid peroxidation. In this study, we measured the potential of $A$. precatorius extracts to inhibit lipid peroxidation in rat liver microsomes, induced by the $\mathrm{Fe}^{2+}$ /ascorbate system (Figure 6). Different extracts protected against lipid peroxidation induced by $\mathrm{Fe}^{2+}$, considerably reduced MDA content in a concentration-dependent manner. APE had the greatest inhibiting activity $(98.70 \pm 2.56 \%)$; with the lowest $\mathrm{IC}_{50}$ value $45.46 \pm 3.71 \mu \mathrm{g} / \mathrm{mL}$. When compared to the activity of standard, (ascorbic acid, $\mathrm{IC}_{50}=48.72 \pm$ $4.23 \mu \mathrm{g} / \mathrm{mL}$ ), inhibiting activity against lipid peroxidation

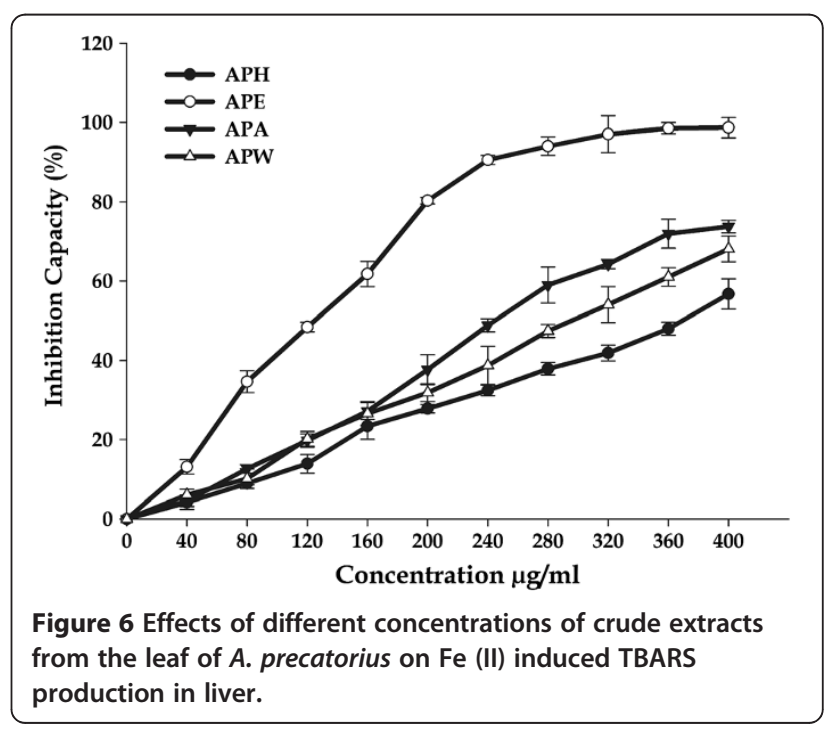


of APE was very high considering that the extract was a mixture of a great number of components against pure compound used as standards. The other extracts (APA, APW and APH) proved to be much weaker inhibitors of lipid peroxidation than APE with the percentage inhibition of $73.75 \pm 1.60 \%, 68.09 \pm 3.26 \%$ and $56.73 \pm 3.81 \%$ respectively with higher $\mathrm{IC}_{50}$ values than that of $\mathrm{APE}$ (Table 2).

\section{Antiproliferative activity}

Deregulation of cell proliferation, together with suppressed apoptosis, is a minimal, common platform for all cancer evolution and progression [66]. Uncontrolled cell division is the primary key in the progression of cancer tumors. In order to evaluate $A$. precatorius as a potential therapy for cancer, different extracts were assayed against a panel of four human cancer cell lines: Colo-205, Y79, HepG2 and SupT1. The antiproliferative effects were quantified in terms of cytotoxicity (percentage inhibition) and $\mathrm{IC}_{50}$ values were also determined with lower $\mathrm{IC}_{50}$ values indicating a higher antiproliferative activity. Out of four extracts tested, only APA and APE demonstrated significantly effective antiproliferative activities in a concentration dependent manner, whereas APH and APW extracts did not inhibit the proliferation of tumor cells, thus indicating their non - cytotoxic properties. In fact, APA was by far the strongest inhibitor of tumor cell proliferation with above $85 \%$ growth inhibition of all tested cell lines, while as APE was slightly weaker inhibitor of growth of cell lines than APA (Figure 7a-7d; Table 3). APA exerted the highest cytotoxicity at a concentration of $200 \mu \mathrm{g} / \mathrm{mL}$ against Colo-205 (92.25 $\pm 2.05 \%)$ and Y79 (92.80 $\pm 6.34 \%)$ cells with an $\mathrm{IC}_{50}$ value of $18.91 \pm 1.06$ and $26.74 \pm$ $1.34 \mu \mathrm{g} / \mathrm{mL}$ respectively. Whereas APE inhibits growth up to $68.33 \pm 1.41 \%$ and $66.40 \pm 5.44 \%$ against Colo-205 and Y79 cells respectively at the same concentration of $200 \mu \mathrm{g} / \mathrm{mL}$ with higher $\mathrm{IC}_{50}$ values of $29.57 \pm 2.02$ and $35.94 \pm 2.10 \mu \mathrm{g} / \mathrm{mL}$ respectively. In addition, APA also showed significant inhibition activity on other two human cancer cell lines HepG2 (88.52 \pm $3.04 \%)$ and SupT1 $(94.12 \pm 3.34 \%)$ at $200 \mu \mathrm{g} / \mathrm{mL}$ with the

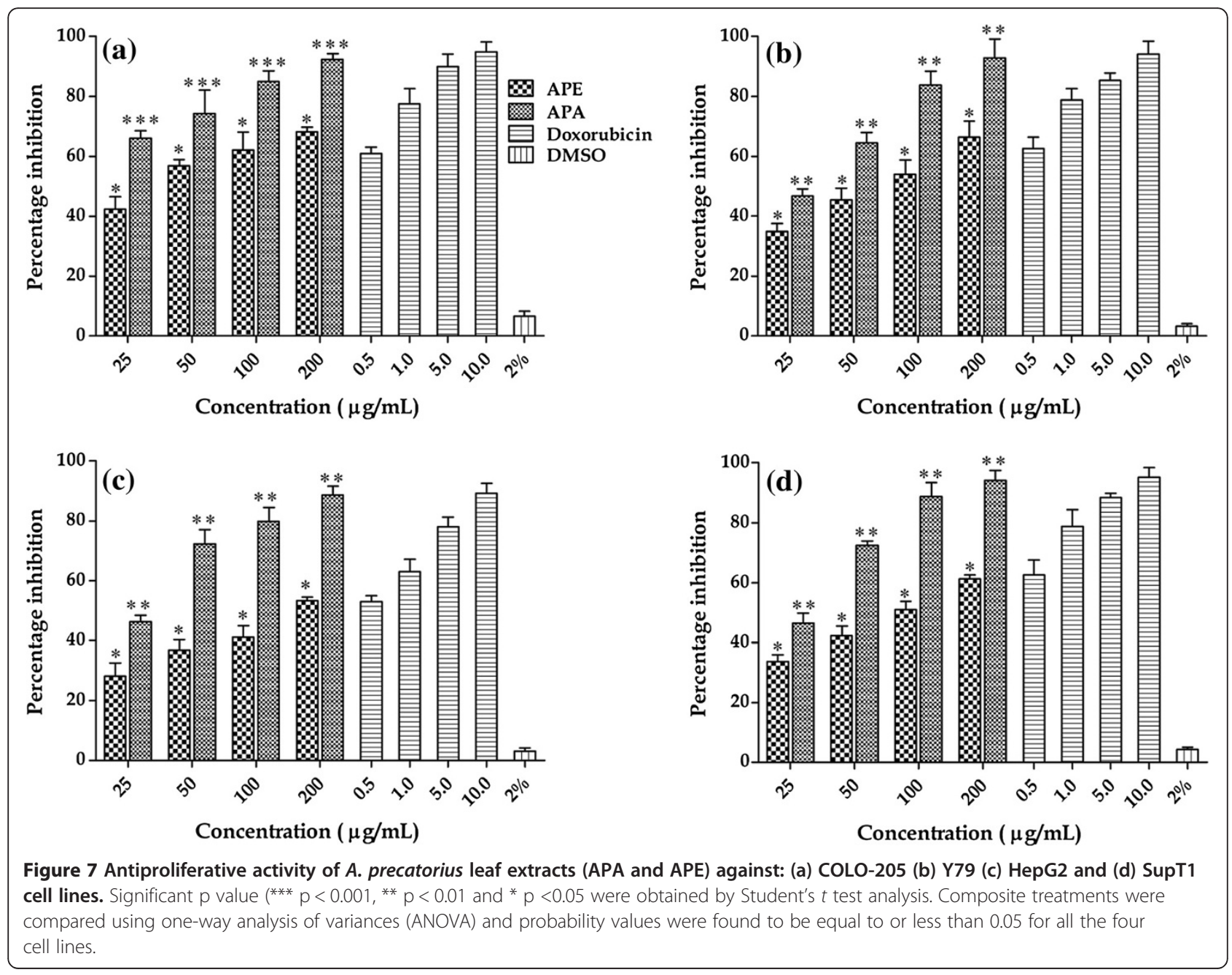


Table 3 Percentage inhibition of cancer cell proliferation and IC 50 values

\begin{tabular}{|c|c|c|c|c|c|c|c|c|}
\hline \multirow[t]{3}{*}{ Sample } & \multicolumn{8}{|c|}{ Type of cell line } \\
\hline & \multicolumn{2}{|c|}{ Colo - 205} & \multicolumn{2}{|c|}{ Y79 } & \multicolumn{2}{|c|}{ HepG2 } & \multicolumn{2}{|c|}{ SupT1 } \\
\hline & $\begin{array}{c}\text { \%age } \\
\text { Inhibition }\end{array}$ & $\begin{array}{l}\mathrm{IC}_{50} \\
\text { Value }\end{array}$ & $\begin{array}{c}\% \text { age } \\
\text { Inhibition }\end{array}$ & $\begin{array}{l}\mathrm{IC}_{50} \\
\text { Value }\end{array}$ & $\begin{array}{c}\% \text { age } \\
\text { Inhibition }\end{array}$ & $\begin{array}{l}\mathrm{IC}_{50} \\
\text { Value }\end{array}$ & $\begin{array}{c}\% \text { age } \\
\text { Inhibition }\end{array}$ & $\begin{array}{l}\mathrm{IC}_{50} \\
\text { Value }\end{array}$ \\
\hline APE $(200 \mu \mathrm{g} / \mathrm{mL})$ & $68.33 \pm 1.41^{*}$ & $29.57 \pm 2.02$ & $66.40 \pm 5.44^{*}$ & $35.94 \pm 2.10$ & $53.33 \pm 1.21^{*}$ & $44.31 \pm 3.07$ & $61.34 \pm 1.32^{*}$ & $37.00 \pm 2.38$ \\
\hline APA $(200 \mu \mathrm{g} / \mathrm{mL})$ & $92.25 \pm 2.05^{* * *}$ & $18.91 \pm 1.06$ & $92.80 \pm 6.34^{*}$ & $26.74 \pm 1.34$ & $88.52 \pm 3.04^{* *}$ & $27.03 \pm 1.03$ & $94.12 \pm 3.34^{* *}$ & $26.89 \pm 3.24$ \\
\hline Doxorubicin (Standard) $10 \mu \mathrm{g} / \mathrm{mL}$ & $94.81 \pm 3.42$ & $0.41 \pm 0.08$ & $94.20 \pm 4.11$ & $0.39 \pm 0.10$ & $89.18 \pm 3.42$ & $0.47 \pm 0.08$ & $95.20 \pm 3.11$ & $0.39 \pm 0.11$ \\
\hline DMSO 2\% (Solvent control) & $6.67 \pm 1.67$ & - & $3.33 \pm 0.78$ & - & $3.13 \pm 1.01$ & - & $4.33 \pm 0.78$ & - \\
\hline
\end{tabular}

Values were the means of four replicates \pm standard deviation (SD). Significant $p$ value $\left(* * * p<0.001,{ }^{* *} p<0.01\right.$ and ${ }^{*} p<0.05$ were obtained by Student's $t$ test analysis. Composite treatments were compared using one-way analysis of variances (ANOVA) and probability values were found to be equal to or less than 0.05 for all the four cell lines.

$\mathrm{IC}_{50}$ value $27.03 \pm 1.03$ and $26.89 \pm 3.24 \mu \mathrm{g} / \mathrm{mL}$ respectively. The APE showed moderate ability to inhibit cancer cell growth in a concentration-dependent manner with $\mathrm{IC}_{50}$ value of $44.31 \pm 3.07 \mu \mathrm{g} / \mathrm{ml}$ for HepG2 and $37.00 \pm$ $2.38 \mu \mathrm{g} / \mathrm{ml}$ for SupT1.

The criterion for cytotoxicity for the crude extracts, as established by the National Cancer Institute (NCI), is an $\mathrm{IC}_{50}$ value lower than $30 \mu \mathrm{g} / \mathrm{mL}$ [67]. In this study, the APA crude extract displays an $\mathrm{IC}_{50}$ values less than $30 \mu \mathrm{g} / \mathrm{mL}$ in all the four tested cell lines, which established APA as more active extract than APE. Comparatively, Doxorubicin, an anticancer drug used in this study as a positive control, demonstrated $\mathrm{IC}_{50}$ values in the tumor cell lines ranging from $0.39-0.47 \mu \mathrm{g} / \mathrm{mL}$. Although, the activity of APA and APE are weak in comparison to the standard drug, which could be due to the crude nature of the extracts and can be further enhanced by the purification.

\section{Assessment of drug toxicity}

The cytotoxic effect of APA and APE was studied in murine peritoneal macrophages using the MTT method. The results clearly indicated that plant extracts were virtually nontoxic and had no inhibitory effect on cell proliferation in peritoneal macrophages and there was minimal reduction in cell survivability (Figure 8). The percentage viability was above $90 \%$ at the highest concentration of $200 \mu \mathrm{g} / \mathrm{mL}$. This suggests that APA and APE extracts did not show any kind of toxic effect on the normal cells. Therefore, the cytotoxicity of the active extracts was found to be highly selective against the cancer cell lines used.

During the past decade, both in vivo and in vitro studies have suggested that natural antioxidants such as phenolics, carotenoids, tocotrienols exhibit antitumor activities by inhibiting the growth and proliferation of many cancer cells such as breast, lung and liver cancer cells [68-71]. These observations and reports (with regard to the cytotoxicity of the plant extracts) indicate that there are great differences among the antiproliferative activity of the same plant species, depending on plant parts and extraction solvents used. Furthermore, the different cell lines vary in their sensitivity to the same plant extract.

\section{Conclusion}

This work has gathered experimental evidence that $A$. precatorius leaf extracts contained substantial amount of polyphenols and flavonoids and exhibited significant antioxidant activity by effectively scavenging various free radicals. Additionally, it has been demonstrated that the A. precatorius leaf extracts (APA and APE) are potential antiproliferative agents without any toxic effect on normal cells. The antioxidant and antiproliferative activities might be due to the synergistic actions of bioactive compounds present in them. Therefore, the plant has promising compounds to be tested as potential antioxidant drugs for treatment of diseases resulting from oxidative stress. However, these findings warrant extensive studies on chemical profiles and mechanistic action of antiproliferative and antioxidant activities. The study will be helpful to understand this important herbal medicine and further studies are underway in our laboratory.

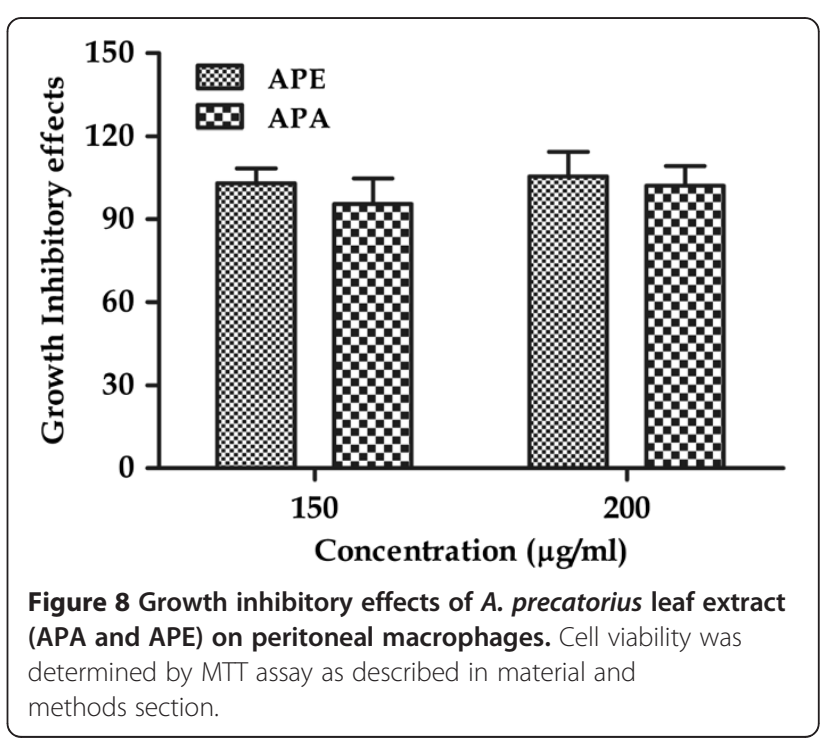




\section{Competing interests}

The authors declare that they have no competing interests.

\section{Authors' contributions}

MZG conceived the study, carried out all the experimentation, acquisition and analysis of data and drafting of the manuscript. FA was involved in cell culturing, MTT assay. AKK provided technical support and advice in cytotoxic studies. IAQ helped in drafting and revision of manuscript. IAG conceived, designed, supervised the study and revised the manuscript. All authors have read and approved the final manuscript.

\section{Acknowledgement}

The authors would like to thank Central Research Institute of Unani Medicine, Hyderabad Andhra Pradesh for providing the plant material. Authors gratefully acknowledge the help of S. Chandrasekaran, Research Scholar, Dept. of Animal Sciences, UoH in animal studies. The authors; MZG and FA acknowledge the financial support in the form of Senior Research Fellowship (SRF) from Council of Scientific and Industrial Research (CSIR) and University Grants Commission (UGC), New Delhi, India respectively. Authors are also thankful to DBT-CREBB, DBT-FIST and UGC-SAP - CAS, UGC-XI plan seed money for supporting infra structural facilities of Department of Plant Sciences and School of Life Sciences.

\section{Author details}

${ }^{1}$ Department of Plant Sciences, School of Life Sciences, University of Hyderabad, Prof. C. R. Rao Road, Gachibowli, Hyderabad 500 046, India. ${ }^{2}$ Department of Biotechnology, School of Life Sciences, University of Hyderabad, Prof. C. R. Rao Road, Gachibowli, Hyderabad 500 046, India.

Received: 2 November 2012 Accepted: 21 February 2013 Published: 2 March 2013

\section{References}

1. Verma AR, Vijayakumar M, Mathela CS, Rao CV: In vitro and in vivo antioxidant properties of different fractions of Moring oleifera leaves. Food Chem Toxicol 2009, 47:2196-2201.

2. Devasagayam TPA, Tilak JC, Boloor KK, Sane KS, Ghaskadbi S, Lele RD: Free radicals and antioxidants in human health: current status and future prospects. J Assoc Physicians India 2004, 52:794-804.

3. Guyton KZ, Kensler TW: Oxidative mechanisms in carcinogenesis. Brit Med Bull 1993, 49:523-544.

4. Sun J, Chu YF, Wu X, Liu RH: Antioxidant and antiproliferative activities of common fruits. J Agric Food Chem 2002, 50:7449-7454.

5. Matito C, Mastorakou F, Centelles JJ, Torres JL, Cascante M: Antiproliferative effect of antioxidant polyphenols from grape in murine Hepa-1c1c7. Eur J Nutr 2003, 42:43-49.

6. Halliwell B: Dietary polyphenols: good, bad, or indifferent for your health? Cardiovas Res 2007, 73(2):341-347.

7. Liu H, Qiu N, Ding HH, Yao RQ: Polyphenols contents and antioxidant capacity of 68 Chinese herbals suitable for medical or food uses. Food Res Int 2008, 41:363-370.

8. Mishra KP, Ganju L, Sairam M, Banerjee PK, Sawhney RC: A review of high throughput technology for the screening of natural products. Biomed Pharmacother 2008, 62:94-98

9. Balunas MJ, Kinghorn AD: Drug discovery from medicinal plants. Life Sci 2005, 78:431-441.

10. Boopathy NS, Kathiresan K: Anticancer drugs from marine flora: an overview. J Oncol 2010, 214186:18.

11. Srinivasan P, Vadhanam MV, Arif JM, Gupta C: A rapid screening assay for antioxidant potential of natural and synthetic agents in vitro. Int $\mathrm{J}$ Oncol 2002, 20:983-986.

12. Gul MZ, Bakhshu LM, Ahmed F, Kondapi AK, Qureshi IA, Ghazi IA: Evaluation of Abelmoschus moschatus extracts for antioxidant, free radical scavenging, antimicrobial and antiproliferative activities using in vitro assays. BMC Complement Altern Med 2011, 11:64.

13. Hogan S, Chung H, Zhang L, Li J, Lee Y, Dai Y, Zhou K: Antiproliferative and antioxidant properties of anthocyanin-rich extract from acai. Food Chem 2010, 118:208-214

14. Zhang DM, Wang Y, Tang MQ, Chan YW, Lam HM, Ye WC, Fung KP: Saxifragifolin B from Androsace umbellata induced apoptosis on human hepatoma cells. Biochem Biophys Res Commun 2007, 362:759-765.
15. Deng XK, Yin W, Li WD, Yin FZ, Lu XY, Zang XC, Hua ZC, Cai BC: The antitumor effects of alkaloids from the seeds of Strychnos nux-vomica on HepG2 cells and its possible mechanism. J Ethnopharmacol 2006, 106:179-186.

16. Morton JF: Plants Poisonous to People in Florida and Other Warm Areas. Miami, Florida: Hallmark Press; 1982:45.

17. Manago CC, Alumanah EO: Antidiabetic effect chloroform-methanol extracts of Abrus precatorius seed. J App/ Sci Environ Mgt 2005, 9:85-88.

18. Dymock W, Warden CJH, Hooper D: Pharmacographia Indica. London: Kegan, Paul, Trench, Triibner \& Co; 1890. 1:430.

19. Anonymous: The Wealth of India. Raw Materials. New Delhi, India: Council of Scientific and Industrial Research; 1985. I: A (revised) 1985, 18.

20. Inglett GE, May JF: Econ Bot 1968, 22:326.

21. Morton JF: Atlas of Medicinal Plants of Middle America: Bahamas to Yucatan. Springfield, Illinois: Charles C Thomas; 1981:267.

22. Irvine FR: Woody Plants of Ghana. London: Oxford University Press; 1961:358.

23. Yang J, Paulino R, Janke-Stedronsky S, Abawi F: Free radical scavenging activity and total phenols of noni (Morinda citrifolia L.) juice and powder in processing and storage. Food Chem 2007, 102:302-308.

24. Barreira JCM, Ferreira ICFR, Oliveira MBPP, Pereira JA: Antioxidant activities of the extracts from chestnut flower, leaf, skins and fruit. Food Chem 2008, 107:1106-1113.

25. Prieto P, Pineda M, Aguilar M: Spectophotometric quantitative of antioxidant capacity through the formation of a phosphomolybdenum complex: specific application to the determination of vitamin E. Anal Biochem 1999, 269:337-341.

26. Oyaizu M: Studies on products of browning reaction prepared from glucoseamine. Jpn J Nutri 1986, 44:307-315.

27. Braca A, Sortino C, Politi M: Antioxidant activity of flavonoids from Licania licaniae flora. J Ethnopharmacol 2002, 79:379-381.

28. Hinneburg I, Dorman HJD, Hiltunen R: Antioxidant activities of extracts from selected culinary herbs and spices. Food Chem 2006, 97:122-129.

29. Long LH, Evans PJ, Halliwell B: Hydrogen peroxide in human urine: implications for antioxidant defense and redox regulation. Biochem Biophys Res Commun 1999, 262:605-609.

30. Sreejayan N, Rao MNA: Nitric oxide scavenging by curcuminoids. J Pharm Pharmacol 1997, 49:105-107.

31. Nishikimi M, Rae NA, Tagi K: The occurrence of superoxide anion in the reaction of reduced phenazine methosulphate and molecular oxygen. Biochem Biophys Res Commun 1972, 461:489-494.

32. Ohakawa H, Ohishi N, Yagi K: Assay for lipid peroxides in animal tissues by thiobarbituric acid reaction. Anal Biochem 1979, 95:351-358.

33. Mosmann T: Rapid colorimetric assay for cellular growth and survival: application to proliferation and cytotoxicity assays. $J$ Immunol Methods 1983, 65:55-63.

34. Bhattacharjee S, Gupta G, Bhattacharya P, Mukherjee A, Mujumdar SB, Pal A, Majumdar S: Quassin alters the immunological patterns of murine macrophages through generation of nitric oxide to exert antileishmanial activity. J Antimicrob Chemoth 2009, 63:317-324.

35. Rice-Evans C: Flavonoids and isoflavones: absorption, metabolism and bioactivity. Free Radic Biol Med 2004, 36:827-828.

36. Dixon RA, Xie DY, Sharma SB: Proanthocyanidins-a final frontier in flavonoid research? New Phytol 2005, 165:9-28.

37. Manian R, Anusuya N, Siddhuraju P, Manian S: The antioxidant activity and free radical scavenging potential of two different solvent extracts of Camellia sinensis (L.) O. Kuntz, Ficus bengalensis L. and Ficus racemosa L. Food Chem 2008, 107:1000-1007.

38. Kahkonen MP, Hopia Al, Vuorela HJ, Rauha JP, Pihlaja K, Kujala TS, Heinonen M: Antioxidant activity of plant extracts containing phenolic compounds. J Agr Food Chem 1999, 48:1485-1490.

39. Zheng W, Wang SY: Antioxidant activity and phenolic compounds in selected herbs. J Agr Food Chem 2001, 49:5165-5170.

40. Heck Cl, Mejia EG: Yerba mate tea (Ilex paraguariensis): a comprehensive review on chemistry, health implication, and technological consideration. J Food Sci 2007, 72:138-151.

41. Hakkim FL, Shankar CG, Girija S: Chemical composition and antioxidant property of holy basil (Ocimum sanctum L.) leaves, stems and inflorescence and their in vitro callus cultures. J Agr Food Chem 2007, 55:9109-9117

42. Yen GC, Duh PD, Tsai CL: Relationship between antioxidant activity and maturity of peanut hulls. J Agric Food Chem 1993, 41:67-70. 
43. Siddhuraju P, Mohan PS, Becker K: Studies on the antioxidant activity of Indian laburnum (Cassia fistula L.): a preliminary assessment of crude extracts from stem bark, leaves, flowers and fruit pulp. Food Chem 2002, 79:61-67.

44. Bhandari MR, Kawabata M: Organic acid, phenolic content and antioxidant activity of wild yam (Dioscorea spp.) tubers of Nepal. Food Chem 2004, 88:163-168.

45. Yang $Q M$, Pan $X H$, Kong WB, Yang $H$, Su YD, Zhang L, Zhang $Y$, Yang $Y$, Ding L, Liu G: Antioxidant activities of malt extract from barley (Hordeum vulgare L.) toward various oxidative stress in vitro and in vivo. Food Chem 2010, 118:84-89.

46. Zhao HF, Dong JJ, Lu J, Chen J, Li Y, Shan LJ, Lin Y, Fan W, Gu G: Effects of extraction solvent mixtures on antioxidant activity evaluation and their extraction capacity and selectivity for free phenolic compounds in barley (Hordeum vulgare L.). J Agric Food Chem 2006, 54:7277-7286.

47. Rice-Evans CA, Miller NJ, Paganga G: Structure-antioxidant activity relationships of flavonoids and phenolic acids. Free Rad Biol Med 1996, 20:933-956

48. Schubert A, Pereira DF, Zanin FF, Alves SH, Beck RCR, Athayde ML: Comparison of antioxidant activities and total polyphenolic and methylxanthine contents between the unripe fruit and leaves of Ilex paraguariensis A. St Hil Pharmazie 2007, 62:876-880.

49. Tung YT, Wu JH, Huang $\mathrm{CY}$, Kuo YH, Chang ST: Antioxidant activities and phytochemical characteristics of extracts from Acacia confuse bark. Bioresour Technol 2009, 100:509-514.

50. Chandra S, Mejia EG: Polyphenolic compounds, antioxidant capacity, and quinone reductase activity of an aqueous extract of Ardisia compressa in comparison to mate (llex paraguariensis) and green (Camellia sinensis) teas. J Agric Food Chem 2004, 52:3583-3589.

51. Shyamala BN, Gupta S, Lakshmi A, Prakash J: Leafy vegetable extracts antioxidant activity and effect on storage stability of heated oils. Innovative Food Sci Emerging Technol 2005, 6:239-245.

52. Adedapo AA, Jimoh FO, Afolayan AJ, Masika PJ: Antioxidant activities and phenolic contents of the methanol extracts of the stems of Acokanthera oppositifolia and Adenia gummifera. BMC Complement Altern Med 2008, 8:54.

53. Tsimogiannis DI, Oreopoulou V: Free radical scavenging and antioxidant activity of 5, 7, 3'4' hydroxy-substituted flavonoids. Innovative Food Sci Emerging Technol 2004, 5:523-528.

54. Moncada S, Palmer RMJ, Higgs EA: Nitric oxide: physiology, pathophysiology, and pharmacology. Pharmacol Rev 1991, 43:109-142.

55. Tsai CH, Stern A, Chiou JF, Chern CL, Liu TZ: Rapid and specific detection of hydroxyl radical using an ultraweak chemiluminescence analyser and a low-level chemiluminescence emitter: application to hydroxyl radical scavenging ability of aqueous extracts of food constituents. J Agric Food Chem 2001, 49:2137-2141.

56. Gülçin I, Elmastaş M, Aboul-Enein HY: Determination of antioxidant and radical scavenging activity of basil (Ocimum basilicum) assayed by different methodologies. Phytother Res 2007, 21:354-361.

57. Sacan O, Yanardag R: Antioxidant and antiacetylcholinesterase activities of chard (Beta vulgaris L. var. cicla). Food Chem Toxicol 2010, 48:1275-1280

58. Sroka Z, Cisowski W: Hydrogen peroxide scavenging, antioxidant and antiradical activity of some phenolic acids. Food Chem Toxicol 2003, 41:753-758.

59. Nakayama T: Suppression of hydroxyperoxide-induced cytotoxicity by polyphenols. Cancer Res 1994, 54:1991-1993.

60. Bourgou S, Ksouri R, Bellila A, Skandrani I, Falleh H, Marzouk B: Phenolic composition and biological activities of Tunisian Nigella sativa L. shoots and roots. Compte Rendu de Biologies 2008, 331:48-55.

61. Ksouri R, Falleh H, Megdiche W, Trabelsi N, Mhamdi B, Chaieb K, Bakrouf A, Magné C, Abdelly C: Antioxidant and antimicrobial activities of the edible medicinal halophyte Tamarix gallica $\mathrm{L}$. and related polyphenolic constituents. Food Chem Toxicol 2009, 47:2083-2091.

62. Szekanecz Z, Koch AE: Mechanisms of disease: angiogenesis in inflammatory diseases. Nat Clin Pract Rheum 2007, 3:635-643.

63. Dahl MK, Richardson T: Photogeneration of superoxide anion in serum of bovine milk and in model systems containing riboflavin and amino acids. J Dairy Sci 1978, 61:400-407.

64. Aruoma O: Assessment of potential pro-oxidant and antioxidant actions. J Am Oil Chem Soc 1996, 73:1617-1625.
65. Pulido R, Bravo L, Saura-Calixto F: Antioxidant activity of dietary polyphenols as determined by a modified ferric reducing/antioxidant power assay. J Agric Food Chem 2000, 48:3396-3402.

66. Evan $\mathrm{Gl}$, Vousden $\mathrm{KH}$ : Proliferation, cell cycle and apoptosis in cancer. Nature 2001, 411:342-348.

67. Suffness M, Pezzuto JM: Assays related to cancer drug discovery. In Methods in Plant Biochemistry: Assays for Bioactivity, Volume 6. Edited by Hostettmann K. London: Academic; 1990:71-133.

68. Van PG: Carotenoids and cancer: an update with emphasis on human intervention studies. Eur J Cancer 1993, 29(A):1335-1344.

69. Eberhardt MV, Lee CY, Liu RH: Antioxidant activity of fresh apples. Nature 2000, 405:903-904.

70. Wada S, Satomi Y, Murakoshi M, Noguchi N, Yoshikawa T, Nishino H: Tumor suppressive effects of tocotrienol in vivo and in vitro. Cancer Lett 2005, 229:181-191.

71. Nesaretnam K, Stephen R, Dils R, Darbre P: Tocotrienols inhibit the growth of human breast cancer cells irrespective of estrogen receptor status. Lipids 1998, 33:461-469.

doi:10.1186/1472-6882-13-53

Cite this article as: Gul et al:: Antioxidant and antiproliferative activities of Abrus precatorius leaf extracts - an in vitro study. BMC Complementary and Alternative Medicine 2013 13:53.

\section{Submit your next manuscript to BioMed Central and take full advantage of:}

- Convenient online submission

- Thorough peer review

- No space constraints or color figure charges

- Immediate publication on acceptance

- Inclusion in PubMed, CAS, Scopus and Google Scholar

- Research which is freely available for redistribution

Submit your manuscript at www.biomedcentral.com/submit
C) Biomed Central 